\title{
EKSPLORASI PROBIOTIK LOKAL UNTUK PERBAIKAN PEMBIBITAN DAN PEMBESARAN LELE SANGKURIANG
}

\section{LOCAL PROBIOTIC EXPLORATION FOR IMPROVEMENT OF SANGKURIANG SEEDING AND RETREATING}

\section{Indra Warman dan Novita Hamron}

\author{
Prodi Budidaya Perairan Fakultas Pertanian Universitas Ratu Samban \\ Jl. Jenderal Sudirman No. 87 Arga Makmur Kabupaten Bengkulu Utara \\ Email : indraabyu@ymail.com
}

\begin{abstract}
ABSTRAK
Ikan lele merupakan salah satu jenis ikan air tawar yang cukup digemari masyarakat Indonesia. Ikan lele harga relatif murah, mudah dibudidayakan, dan memiliki kandungan gizi yang tinggi. Usaha untuk meningkatkan hasil budidaya lele sudah dilakukan dengan berbagai banyak cara, salah satunya probiotik. Tujuan pemberian probiotik adalah untuk memperbaiki kualitas air. Penelitian dilaksanakan pada April sampai bulan Juli 2019, di Kolam Percobaan Fakultas Pertanian Universitas Ratu Samban Kabupaten Bengkulu Utara Propinsi Bengkulu. Penelitian menggunakan rancangan acak kelompok (RAK) dua faktor. Faktor pertama jenis probiotik (J), terdiri atas 2 taraf yaitu : J1 : jenis ikan laut, J2 : jenis ikan tawar. Faktor kedua dosis probiotik (P), terdiri atas 4 taraf yaitu : P1 : dosis $1 \mathrm{ml}$ probiotik per 10 liter air kolam, P2 : dosis 1,5 ml probiotik per 10 liter air kolam, P3 : d dosis $2 \mathrm{ml}$ probiotik per 10 liter air kolam, P4 : dosis $2,5 \mathrm{ml}$ probiotik per 10 liter air kolam. Perlakuan di atas diulang tiga kali sehingga terdapat 24 satuan percobaan. Penelitian ini bertujuan untuk mendapatkan informasi tentang eksplorasi probiotik lokal dengan dosis yang tepat untuk perbaikan pembibitan dan pembesaran lele sangkuriang. Hasil penelitian menunjukkan bahwa pemanfaatan jenis/sumber probiotik berasal dari ikan tawar maupun ikan laut ternyata mempunyai efek sama, namun terdapat potensi bahwa jenis/sumber probiotik ikan laut menghasilkan berat mutlak dan panjang mutlak yang lebih tinggi. Dosis probiotik mempunyai potensi sama antara dosis rendah sampai tinggi, namun terdapat kecenderungan bahwa dosis probiotik 1,5 ml/10 1 air menghasilkan panjang mutlak dan berat mutlak yang lebih tinggi. Tidak terdapat interaksi antara jenis probiotik dan dosis probiotik.
\end{abstract}

Kata kunci : limbah, ikan, probiotik, lele, sangkuriang

\section{ABSTRACT}

Catfish is one type of freshwater fish that is quite popular with the people of Indonesia. Catfish prices are relatively cheap, easily cultivated, and have high nutritional content. Efforts to improve the yield of catfish farming have been done in many different ways, one of which is probiotics. The purpose of giving probiotics is to improve water quality. The study was conducted from April to July 2019, in the Experimental Pool of the Faculty of Agriculture, University of Ratu Samban, Bengkulu Utara, Bengkulu Province. The study used a two-factor randomized block design. The first factor is the type of probiotics $(\mathrm{J})$, consisting of 2 levels, namely: J1: types of sea fish, J2: types of fresh fish. The second factor is the dose of probiotics $(P)$, consisting of 4 levels, namely: P1: dose of $1 \mathrm{ml}$ of probiotics per 10 liters of water, P2: dose of $1.5 \mathrm{ml}$ of probiotics per 10 liters of water, P3: dose of $2 \mathrm{ml}$ of 
probiotics per 10 liters water, P4: dose of $2.5 \mathrm{ml}$ of probiotics per 10 liters of water. The above treatment was repeated three times so that there were 24 experimental units. This study aims to obtain information about the exploration of local probiotics with the right dosage for nursery improvement and enlargement of sangkuriang catfish. The results showed that the utilization of probiotic types / sources originating from both fresh fish and sea fish turned out to have the same effect, but there was potential that the types / sources of probiotic fish produced higher absolute weight and absolute length. Probiotic doses have the same potential between low and high doses, but there is a tendency that $1.5 \mathrm{ml} / 10 \mathrm{l}$ water probiotic doses produce higher absolute length and absolute weight. There is no interaction between the types of probiotics and probiotic doses.

Keywords: waste, fish, probiotics, catfish, sangkuriang

\section{PENDAHULUAN}

Ikan lele merupakan salah satu jenis ikan air tawar yang cukup digemari masyarakat Indonesia, selain harga yang relatif murah, mudah dibudidayakan dan memiliki kandungan gizi yang tinggi. Kebutuhan ikan lele di Indonesia setiap tahunnya selalu meningkat. Hal ini sebagai gambaran bahwa pertumbuhan Industri Kecil Menengah (IKM) dalam pemanfaatan ikan lele semakin berkembang, sehingga mampu menumbuhkan wirausahawan baru bidang perikanan. Dahulu kala ikan lele dipandang ikan murahan dan hanya dikonsumsi oleh keluarga petani, sekarang ikan lele merupakan komoditas yang sangat disukai oleh masyarakat (Sukardono et al., 2013). Selain itu rasa daging yang khas, serta cara memasak dan menghidangkan secara tradisional, menjadikan menu sajian ikan lele digemari masyarakat luas.
Banyak hasil samping dari produksi ikan lele yang dapat dimanfaatkan, seperti hasil penelitian Ferazuma, Marliyati dan Amalia (2011), dalam hal ini kepala ikan lele dumbo yang kaya kalsium dapat diolah menjadi tepung dan diaplikasikan pada pembuatan produk crackers. Menurut Mervina, Kusharto dan Merliyati (2012), ikan lele dapat dibuat menjadi tepung, sebagai bahan substitusi tepung ikan lele dan isolat protein kedelai untuk membuat biscuit yang berprotein tinggi. Limbah ikan juga bisa berpotensi sebagai bahan pembuatan probiotik yang berfungsi perbaikan kualitas air maupun perbaikan kualitas pakan.

Probiotik adalah mikroorganisme hidup yang mempunyai sifat menguntungkan bagi hewan inang, sehingga populasi mikroorganisme patogen yang merugikan tidak menjadi bertambah. Probiotik merupakan makanan tambahan bagi hewan inang berupa sel 
mikroorganisme (mikroba) atau sebagai pakan mikroskopik yang bertujuan memenangkan kompetisi dalam sistem saluran pencernaan ikan (hewan inang) dengan bakteri merugikan (patogen). Wang et al., (2008) dalam Ahmadi (2012) menjelaskan bahwa bakteri probiotik menghasilkan enzim yang mampu mengurai senyawa kompleks menjadi sederhana sehingga siap digunakan ikan. Pemberian input dalam bentuk probiotik pada air kolam dapat mengubah dan memperbaiki sifat biologi maupun kimia air. Salah satu contoh jenis probiotik untuk perbaikan kesuburan air adalah probiotik berbahan limbah ikan. Limbah ikan yang dimaksud disini adalah limbah ikan yang berasal dari ikan air tawar dan ikan laut. Limbah ikan yang dihasilkan dari penjual ikan disepanjang pantai di Bengkulu maupun penjual ikan di pasar tradisional selama ini tidak dimanfaatkan sebagai bahan apapun. Limbah ikan selama ini justru menimbulkan pencemaran udara dengan bau busuk yang menyengat. Limbah ikan selama ini tidak dimanfaatkan dan sebagai sumber pencemar lingkungan.

Berdasarkan uraian di atas, maka perlu dilakukan penelitian untuk mendapatkan informasi tentang eksplorasi probiotik lokal untuk perbaikan pembibitan dan pembesaran lele sangkuriang. Hasil penelitian ini diharapkan mendapatkan informasi yang tepat tentang probiotik berbahan limbah ikan sebagai sumber probiotik lokal sehingga menjadi bahan alternatif probiotik pada budidaya lele sangkuriang di daerah khususnya di pesisir Bengkulu Utara.

Petani ikan selama ini tergantung pada penggunaan probiotik buatan pabrik untuk memperbaiki kualitas air pada budidaya ikan miliknya. Selain harganya mahal, probiotik sintetis buatan pabrik diduga memiliki dampak buruk bagi kelangsungan dalam budidaya ikan. Dampak negatif dari penggunaan probiotik sintetis adalah efisiensi dalam budidaya ikan dan perhitungan keuntungan dalam budidaya ikan khususnya lele sangkuriang tidak tercapai. Perlu dilakukan penggantian produk dengan menggunakan probiotik lokal, karena probiotik lokal berbahan limbah ikan ini relatif mudah didapat, dan aman terhadap lingkungan. Menurut Abun (2006), limbah perikanan memiliki potensi baik berupa protein dan sebagainya yang dapat diolah secara kimiawi maupun biologi untuk menghasilkan produk yang lebih bermanfaat dan bernilai ekonomis. Penelitian bertujuan untuk mendapatkan informasi tentang eksplorasi probiotik lokal untuk 
perbaikan pembibitan dan pembesaran lele sangkuriang. terutama pada bahan limbah jenis ikan dan dosis yang tepat.

\section{BAHAN DAN METODE}

Penelitian dilaksanakan pada

bulan April sampai bulan Juli 2019, bertempat di Kolam Percobaan Fakultas Pertanian Universitas Ratu Samban Kabupaten Bengkulu Utara Propinsi Bengkulu. Bahan yang digunakan adalah probiotik yang terfomulasi dalam probiotik lokal dari bahan limbah ikan, pakan ikan PF-800 yang mengandung protein $39-41 \%$ dan benih ikan lele ukuran 5-7 cm. Alat yang digunakan adalah aerator merk Amara BS-410, selang berfungsi untuk menyalurkan oksigen, termometer (pengukur suhu), kertas $\mathrm{pH}$ Indikator berfungsi untuk mengukur tingkat keasaman dan kebasaan air, kolam $100 \mathrm{~cm} \mathrm{x} 100 \mathrm{~cm}$ x $50 \mathrm{~cm}$ berfungsi sebagai kolam percobaan, kantong plastik untuk membungkus pakan ikan yang telah ditimbang sesuai dengan berat ikan menurut biomasa ikan, timbangan digital untuk menimbang berat ikan/pakan, penggaris untuk mengukur panjang ikan, kamera untuk mendokumentasikan pelaksanaan penelitian, dan alat tulis untuk mencatat data penelitian.

Penelitian ini dilaksanakan dengan menggunakan rancangan acak kelompok
(RAK) dengan dua faktor. Faktor pertama perlakuan eksplorasi probiotik jenis limbah ikan (J), terdiri atas 2 taraf yaitu : J1 : jenis ikan laut, J2 : jenis ikan tawar. Faktor kedua perlakuan dosis probiotik (P), terdiri atas 4 taraf yaitu : P1 : dosis probiotik $100 \mathrm{ml}$ per $1 \mathrm{~m}^{3}$ air kolam, P2 : dosis probiotik $150 \mathrm{ml}$ per $1 \mathrm{~m}^{3}$ air kolam, P3 : dosis probiotik $200 \mathrm{ml}$ per $1 \mathrm{~m}^{3}$ air kolam, P4 : dosis probiotik $250 \mathrm{ml}$ per 1 $\mathrm{m}^{3}$ air kolam. Dari perlakuan tersebut di atas diulang tiga kali sehingga terdapat 24 satuan percobaan. Setiap satu satuan percobaan terdiri atas satu kolam percobaan berukuran $100 \mathrm{~cm}$ x $100 \mathrm{~cm} \mathrm{x}$ $50 \mathrm{~cm}$. Penempatan semua perlakuan dalam satu kelompok percobaan dilakukan secara acak sesuai rancangan acak kelompok.

Kolam yang digunakan untuk pemeliharaan ikan lele adalah 24 buah dengan ukuran $100 \mathrm{~cm}$ x $100 \mathrm{~cm}$ x $50 \mathrm{~cm}$. Kolam percobaan terbuat dari kerangka bambu dan dilapisi terpal plastik. Air yang digunakan adalah air berasal dari kolam yang berada di belakang kantor Dinas Perikanan dan Kelautan Kabupaten Bengkulu Utara.

Bahan probiotik yang digunakan adalah limbah ikan yang diiris-iris atau dicacah dengan ukuran $\pm 1 \mathrm{~cm}$ masingmasing sebanyak $5 \mathrm{~kg}$, air cucian beras 50 liter (didapat dari 25 liter beras yang dicuci dengan 50 liter air) dan gula 
merah dari kelapa (gula Jawa) $5 \mathrm{~kg}$ yang kemudian diiris halus. Air sisa cucian beras dicampur dengan gula merah yang telah diiris halus dimasukkan dalam ember besar kemudian diaduk sampai gula larut (air sisa cucian beras berubah warna menjadi coklat) kemudian dimasukkan bahan probiotik limbah ikan, diaduk kembali sampai tercampur merata. Campuran tersebut dimasukkan ke wadah jerigen dengan dipasang selang yang dihubungkan ke dalam air pada wadah bekas air mineral yang terisi air. Campuran tersebut disimpan di dalam jerigen dan didiamkan sampai satu bulan. Setelah satu bulan probiotik sudah dapat digunakan. Probiotik yang telah jadi, diaplikasikan ke kolam percobaan sesuai perlakuan dalam penelitian ini.

Dalam melaksanakan penelitian, ikan uji terlebih dahulu diaklimatisasikan selama 15 - 30 menit dengan padat penebaran masing masing 100 ekor/kolam. Selama diaklimatisasikan lanjutan ikan uji diberikan pakan yang sama pada setiap perlakuan. Selanjutnya pemberian pakan ikan dilakukan sesuai dengan konversi pakan yang telah ditentukan berdasarkan bobot biomasa ikan. Pakan yang diberikan pada setiap perlakuan yaitu 5\% dari berat total tubuh ikan. Pakan diberikan 3 kali sehari yaitu pada pagi pukul 08.00 WIB, siang pukul
13.00 WIB dan sore pada pukul 16.00 WIB. Data dikumpulkan dari semua ikan sampel yang diukur. Data yang terkumpul selanjutnya dianalisis secara statistik. Pengukuran ikan lele meliputi:

Bobot rata-rata benih ikan ditimbang dengan menggunakan timbangan digital secara akumulasi. Rumus yang digunakan sebagai berikut :

$$
\boldsymbol{w}=\frac{\mathbf{h}}{\mathbf{j}}
$$

\section{Keterangan}

$\mathrm{w}=$ bobot rata-rata ikan $(\mathrm{g})$

$\mathrm{b}=$ biomasa ikan $(\mathrm{g})$

$\mathrm{j}=$ jumlah ikan yang ditimbang

(ekor)

Panjang rata-rata merupakan panjang total benih ikan lele (pengukuran dari ujung kepala sampai dengan ujung ekor) (Wahyuningsih dan Ing. T.A.B. 2006). Rumus yang digunakan sebagai berikut :

$$
\operatorname{Pr}=\frac{\mathbf{P a}}{\mathbf{j}}
$$

Keterangan:

$\mathrm{Pr}=$ panjang rata-rata $(\mathrm{cm})$

$\mathrm{Pa}=$ jumlah panjang total (ekor)

$\mathrm{J}=$ jumlah ikan yang diukur (ekor)

Panjang mutlak benih ikan lele diukur dengan menggunakan rumus menurut Effendi (1997) sebagai berikut :

Keterangan :

$$
\mathbf{P t}=\mathbf{L t}-\mathbf{L o}
$$

$\mathrm{Pt}=$ pertambahan panjang mutlak

$\mathrm{Lt}=$ rata-rata panjang individu pada hari ke-t $(\mathrm{cm})$ 
Lo $=$ rata-rata panjang individu pada hari ke-0 $(\mathrm{cm})$

Tingkat kelangsungan hidup adalah perbandingan antara jumlah ikan yang hidup pada akhir dan awal penelitian. Rumus yang digunakan menurut Effendi (1997) adalah :

$$
S R=\frac{\mathrm{Nt}}{\mathrm{No}} \times 100 \%
$$

Keterangan :

SR = tingkat kelangsunagn hidup 100\%

$\mathrm{Nt}=$ jumlah ikan yang dihasilkan pada waktu t (ekor)

No $=$ jumlah ikan awal tebar (ekor)

Parameter kualitas air yang diukur adalah pH, DO, dan suhu. Parameter DO dan $\mathrm{pH}$ diukur menggunakan DO meter dan $\mathrm{pH}$ meter, dan parameter suhu di ukur menggunakan termometer.

Data hasil pengamatan dianalisis dengan sidik ragam untuk mengetahui pengaruh perlakuan yang dicobakan. Apabila dari hasil analisis tersebut berpengaruh nyata maka dilanjutkan dengan uji wilayah berganda Duncan (DMRT) pada taraf kepercayaan 95\% (Mattjik dan Sumertajaya, 2006).

\section{HASIL DAN PEMBAHASAN}

Rekapitulasi sidik ragam pertumbuhan lele sangkuriang dapat dilihat pada Tabel 1. Hasil analisis ragam menunjukkan bahwa tidak terdapat pengaruh nyata perlakuan probiotik dan dosis probiotik terhadap berat mutlak dan panjang mutlak. Pada interaksi antara probiotik dan dosis probiotik menunjukkan tidak berpengaruh nyata pada semua variabel pengamatan baik berat mutlak maupun dosis probiotik ditunjukkan Tabel 1.

Pada variabel berat mutlak menunjukkan bahwa perlakuan jenis/sumber probiotik tidak berpengaruh nyata terhadap berat mutlak. Terdapat kecenderungan bahwa jenis probiotik yang berasal dari ikan laut menghasilkan berat mutlak yang lebih tinggi. Hal ini menunjukkan bahwa terdapat jenis atau sumber probiotik yang potensial dalam perbaikan kualitas air budidaya ikan. Meskipun hasil ini belum secara tegas menyatakan bahwa sumber probiotik yang terbaik. Pada perlakuan dosis probiotik tidak berpengaruh nyata terhadap variabel berat mutlak namun terdapat kecenderungan bahwa dosis probiotik 1,5 ml/10 1 air menghasilkan berat mutlak yang lebih tinggi ditunjukkan Tabel 2. Hal ini menunjukkan bahwa terdapat peluang untuk menghasilkan dosis probiotik terbaik dalam rangka mendukung pertumbuhan lele sangkuriang, meskipun dalam penelitian ini belum secara tegas menyatakan dosis terbaiknya. Lele sangkuriang memakan pakan alami berupa cacing, plankton, jenis serangga 
kecil, keong dan lainnya, tetapi dalam budidaya perlu diberikan pakan tambahan yaitu pakan yang banyak mengandung protein hewani. Menurut Mahyuddin dan Kholish (2011), jika pakan yang diberikan banyak mengandung protein nabati, pertumbuhannya lambat. Lele bersifat kanibalisme, yaitu sifat suka memangsa jenisnya sendiri, jika kekurangan pakan.

Pada variabel panjang mutlak menunjukkan bahwa perlakuan jenis probiotik tidak berpengaruh nyata terhadap panjang mutlak. Terdapat kecenderungan bahwa jenis probiotik yang berasal dari ikan laut menghasilkan panjang mutlak yang lebih tinggi. Hal ini menunjukkan bahwa terdapat peluang potensi dalam menghasilkan jenis probiotik terbaik, meskipun dalam penelitian ini belum secara tegas menyatakan jenis probiotik mana yang nyata memperbaiki pertumbuhan lele sangkuriang. Pada perlakuan dosis probiotik menunjukkan bahwa tidak berpengaruh nyata terhadap panjang mutlak. Terdapat kecenderungan bahwa dosis probiotik $1,5 \quad \mathrm{ml} / 10 \quad 1$ air menghasilkan panjang mutlak yang lebih panjang ditunjukkan Tabel 2. Hal ini menunjukkan bahwa terdapat potensi atau peluang dalam menentukan dosis probiotik dalam rangka untuk perbaikan pertumbuhan lele sangkuriang. Menurut Merrifield et al., (2010), probiotik yang diberikan akan berperan dalam meningkatkan pertumbuhan, tingkat kelangsungan hidup, sistem kekebalan tubuh, efisiensi pakan, serta komposisi bakteri yang menguntungkan dalam saluran pencernaan ikan. Menurut Dhingra (1993) bahwa probiotik bermanfaat dalam mengatur lingkungan mikroba pada usus, menghalangi mikroorganisme patogen usus dan memperbaiki efisiensi pakan dengan melepas enzim yang membantu proses pencernaan makanan.

\section{Tabel 1. Rekapitulasi Sidik Ragam Pertumbuhan Lele Sangkuriang}

\begin{tabular}{clcccc}
\hline \multirow{2}{*}{ No } & Variabel pengamatan & $\begin{array}{c}\text { Probiotik } \\
(\mathrm{P})\end{array}$ & $\begin{array}{c}\text { Dosis } \\
(\mathrm{D})\end{array}$ & $\begin{array}{c}\text { Interaksi } \\
(\mathrm{P} \times \mathrm{D})\end{array}$ & KK (\%) \\
\hline 1 & Berat mutlak & $1,19 \mathrm{tn}$ & $0,67 \mathrm{tn}$ & $0,51 \mathrm{tn}$ & 24,43 \\
2 & Panjang mutlak & $0,37 \mathrm{tn}$ & $0,55 \mathrm{tn}$ & $1,62 \mathrm{tn}$ & 17,25 \\
\hline
\end{tabular}

Keterangan: tn = tidak berbeda nyata 
Tabel 2. Rataan Berat Mutlak dan Panjang Mutlak Lele Sangkuriang Akibat Aplikasi Jenis dan Dosis Probiotik yang Berbeda

\begin{tabular}{lcc}
\hline \multicolumn{1}{c}{ Perlakuan } & Berat mutlak (g) & Panjang mutlak (cm) \\
\hline Jenis probiotik : & & 1,95 \\
Ikan tawar (J1) & 1,14 & 2,04 \\
Ikan laut (J2) & 1,27 & \\
\hline Dosis probotik: & & 1,92 \\
1 ml/10 liter air (P1) & 1,07 & 2,12 \\
$1,5 \mathrm{ml} / 10$ liter air (P2) & 1,31 & 1,89 \\
$2 \mathrm{ml} / 10$ liter air (P3) & 1,19 & 2,04 \\
$2,5 \mathrm{ml} / 10$ liter air (P4) & 1,23 & $\mathrm{y}$ \\
\hline
\end{tabular}

Keterangan : angka-angka yang diikuti huruf yang sama pada kolom yang sama tidak berbeda nyata pada uji BNT taraf 5\%.

\section{KESIMPULAN DAN SARAN}

\section{Kesimpulan}

Pemanfaatan jenis probiotik berasal dari ikan tawar maupun ikan laut ternyata mempunyai efek sama, namun terdapat potensi bahwa jenis probiotik ikan laut menghasilkan berat mutlak dan panjang mutlak yang lebih tinggi. Dosis probiotik mempunyai potensi sama antara dosis rendah sampai tinggi, namun terdapat kecenderungan bahwa dosis probiotik 1,5 ml/10 liter air menghasilkan panjang mutlak dan berat mutlak yang lebih tinggi. Tidak terdapat interaksi antara jenis probiotik dan dosis probiotik.

\section{Saran}

Perlu penelitian lanjutan dengan perlakuan jenis/sumber probiotik kombinasi dosis yang berbeda dengan jumlah perlakuan yang lebih banyak guna menjaring potensi perlakuan terbaik pada beberapa jenis ikan yang berbeda.

\section{UCAPAN TERIMA KASIH}

Penelitian ini adalah Penelitian Skim Penelitian Dosen Pemula pendanaan tahun 2019. Terima kasih kepada Direktorat Riset dan Pengabdian Direktorat Jenderal Penguatan Riset dan Pengembangan Kementerian Riset, Teknologi, dan Pendidikan Tinggi yang telah membiayai penelitian ini.

\section{DAFTAR PUSTAKA}

Abun. "Efek Pengolahan Secara Kimiawi dan Biologis Terhadap Kandungan Gizi dan Nilai Energi Metabolis Limbah Ikan Tuna (Thunnus Atlanticus) pada Ayam Broiler". Jurnal Bionatura . Vol. 8, No. 3 (2006): 280 - 291.

Ahmadi, H., Iskandar., Kurniawati., N., 2012. Pemberian Probiotik Dalam Pakan Terhadap 
Pertumbuhan Lele Sangkuriang (Clarias graprienus) Pada Pendederan II. 3 (4) : 99-107

Dhingra, M. M. 1993. Probiotic in Poultry Diet Livestock production and Management. India. Sania Enterprises Indore 452001.

Effendie. 1997. Biologi Perikanan. Yayasan Pustaka Nusatama: Yogyakarta. 163 hal.

Ferazuma, H., Marliyati, S. A. dan Amalia, L. 2011. Substitusi Tepung Kepala Ikan Lele Dumbo (Clarias gariepinus Sp) untuk Meningkatkan Kandungan Kalsium Crac-kers. Jurnal Gizi dan Pangan, 6(1): 18- 26.

Mahyuddin dan Kholish, 2011.Panduan Lengkap Agribisnis Lele. Jakarta: Penebar Swadaya.

Mattjik A A, I. M Sumertajaya., 2006. Perancang Percobaan dengan Aplikasi SAS dan MINITAB. Bogor: IPB Press.
Merrifield DL, Dimitroglou A, Foey A, Davies SJ, Baker RTM, Bøgwald J, Castex M, dan Ring $\varnothing$ E. 2010. The Current Status and Future Focus of Probiotic and Prebiotic Applications for Salmonids. Aquaculture 302:1-18.

Mervina, Kusharto, C. M. dan Marliyati, S.A. 2012. Formulasi Biskuit dengan Substitusi Tepung Ikan Lele Dumbo (Clarias gariepinus) dan Isolat Protein Kedelai (Glycine max) sebagai Makanan Potensial Untuk Anak Balita Gizi Kurang. Jurnal Teknologi dan Industri Pangan.

Sukardono, E., M. Sarma dan K. Sumantadi-nata. 2013. Strategi Pemasaran Restoran Pecel Lele Lela Cabang Pinangranti, Jakarta Timur. Manajemen IKM, 8 (2).

Wahyuningsih, H dan Barus,T.A. 2006. Ikhtiologi. Departemen Biologi Fakultas MIPA Universitas Sumatera Utara, Medan 